\title{
Dioxin-like PCBs and Endometriosis
}

\author{
Kaylon L. Bruner-Tran, PhD [Assistant Professor] and \\ Women's Reproductive Health Research Center Department of Obstetrics and Gynecology \\ Vanderbilt University School of Medicine B-1100, MCN Nashville, TN 37232-2519 Ph: 615-3224196 \\ Fax:615-343-7913 kaylon.bruner-tran@vanderbilt.edu \\ Kevin G. Osteen, PhD [Professor and Director] \\ Women's Reproductive Health Research System Department of Obstetrics and Gynecology \\ Vanderbilt University School of Medicine B-1100, MCN Nashville, TN 37232-2519 Ph: \\ 615-322-4196 Fax: 615-343-7913 Kevin.osteen@vanderbilt.edu
}

\begin{abstract}
A recent survey in the United States identified 287 different chemicals in human cord blood, demonstrating the significant exposure of women and their children to a wide array of environmental toxicants. While reducing contamination and exposure should be an international priority, it is equally appropriate to develop an understanding of the health consequences of increasing world-wide industrialization. Endometriosis, a disease of the female reproductive tract, has emerged as a disease potentially related to environmental exposures. While a number of population-based studies have suggested that a woman's exposure to dioxin-like polychlorinated biphenyls may affect her risk of developing this disease, other studies have failed to find such evidence. In the current manuscript, we will review the limited data regarding polychlorinated biphenyl congeners and endometriosis with a focus on dioxin-like toxicants. We will also discuss the potential importance of early life exposures to these toxicants on the subsequent development of endometriosis.
\end{abstract}

\section{Keywords}

TCDD; PCB; endometriosis; epigenetics; developmental exposure

\section{Introduction}

\begin{abstract}
Humans and animals are exposed to an astonishing array of natural and man-made chemicals that have the capacity to negatively influence normal physiological processes and potentially promote disease. Many of these environmental toxicants are persistent, with long biological half-lives; thus, these agents accumulate within human and animal populations and, importantly, have the capacity to negatively impact the developing fetus during pregnancy. A recent analysis by the Environmental Working Group revealed the presence of 287 different chemicals within human cord blood. Although not every child was exposed to all measured toxicants, no child was without some exposure (EWG, 2005). It is difficult to assess the combinatorial effects of these numerous chemicals on organ specific development or disease processes, but individual toxicants have been linked to childhood and adult cancers, immune disorders, developmental delays and alterations in reproductive tract function (Carpenter, 2006). Not surprisingly, multiple toxicants can act synergistically to induce a more devastating effect (for example, Loeffler and Peterson, 1999; Burton et al, 2002; Zhao et al, 2006), but, as will be discussed later, it is also possible for one toxicant to antagonize the effects of another.
\end{abstract}


Thus, any individual's risk of toxicant-associated disease with be dependent upon the specific combination of toxicants to which they are exposed.

Timing of exposure to toxicants is also of critical importance to determining an individual's risk of disease; thus understanding the mechanisms of action of environmental toxicants on organ systems at each stage of life will be necessary for developing accurate risk assessments. In terms of human health, it will be critical to take appropriate precautions to limit toxicant exposures and construct better clinical strategies to reduce the toxic effects of unavoidable exposures on not only women and their children but also future generations. Among the numerous toxicants identified within human cord blood, 2,3,7,8-tetrachlorodibenzo-p-dioxin (TCDD) has been widely studied because it is considered to be the most highly toxic environmental contaminant ever manufactured (Jacobson-Dickman and Lee, 2009). However, certain structurally related polychlorinated biphenyls (PCBs) exhibit similar biological toxicity as TCDD, and, thus these environmental toxicants likely act in concert to disrupt reproductive functions. In the current manuscript, we discuss the complexity and challenges of determining the potential impact of human exposure to dioxin-like PCBs with a focus on the reproductive tract disease endometriosis.

\section{Environmental Exposure to TCDD and PCBs}

Although TCDD has been introduced to our environment largely as an unwanted byproduct of manufacturing processes and incineration, PCBs have widespread commercial application and were heavily manufactured until being banned in the United States in 1979; a world-wide ban followed a few years later. These organochlorides are extremely resistant to degradation and, due to their lipophilic nature, bioaccumulate and biomagnify within the food chain (Birnbaum, 1994). Among various human or animal populations, ingestion of contaminated food and water is the primary source of TCDD and PCB exposure (Schecter et al, 2002; Harrad et al, 2003; Pompa et al, 2003). Additionally, these environmental toxicants are also carried by weather patterns and can affect human and animal populations at great distances from the original point of production or contamination (Dewailly et al, 1994). Given the toxicity of TCDD and dioxinlike PCBs to endocrine and immune function (Aoki, 2001), it is not surprising that these toxicants have been linked to developmental disorders of the reproductive tract, disruption of pregnancy and diseases such as endometriosis (Woodruff et al, 2008). Nevertheless, epidemiological studies attempting to specifically connect the adult body burden of TCDD and various PCBs to the presence of endometriosis have failed to reach a consensus, perhaps related to both the number and toxicity of individual congeners involved and the inherent complexity of determining the presence and absence of endometriosis within any control population (Rier and Foster, 2003; Heilier et al, 2008; Anger and Foster, 2008). An additional and critical issue within the field of reproductive toxicology is the potential contribution of early life toxicant exposures to the subsequent development of adult disease (Heindel, 2006; Bruner-Tran et al, 2009). It has been demonstrated that the toxic effects of PCBs are greater when exposures occur earlier in life; environmental toxicant exposure occurring during the neonatal period is the most damaging (Crain et al, 2008). Thus, adult body burden assessments studies alone are unlikely to reveal the true association of PCBs or other toxicants relative to the subsequent development of endometriosis if the initial toxin-mediated disruption of reproductive tract cell and tissue function occurred during early life.

Polychlorinated biphenyls (PCBs) are man-made compounds belonging to the simplest class of organochlorides known as chlorinated hydrocarbons (Barbalace, 2003). All PCBs contain 1-10 chlorine atoms attached to two benzene rings connected by a carbon-carbon bond at the 1,1 ' position, resulting in a biphenyl. Thus, all $\mathrm{PCBs}$ have a chemical formula consisting of: $\mathrm{C}_{12} \mathrm{H}_{10-\mathrm{x}} \mathrm{Cl}_{\mathrm{x}}$. During manufacturing processes, $\mathrm{PCBs}$ are formed by electrophilic chlorination of biphenyl with chlorine gas. The family of PCBs consists of 209 possible congeners; the 
name of a congener specifies the total number of chlorine substituents as well as the position of each chlorine. Within biological systems, the toxicity of any PCB congener is dependent upon both the number and position of each chlorine on the biphenyl ring. Greater toxicity is generally associated with a higher number of chlorines; however, PCBs with chlorines in the ortho positions of each ring (positions 2, 2', 6 and 6') are less toxic than non-ortho or monoortho PCBs. Non-ortho PCBs, also known as the coplanar PCBs, bind the aryl hydrocarbon receptor $(\mathrm{AhR})$ and are capable of producing dioxin-like effects within biological systems. As shown in FIGURE 1, these "dioxin-like" PCBs have structural similarity to TCDD and have a much greater biological toxicity than the non-coplanar PCBs. Additionally, since biodegradability of PCB congeners is also dependent upon number and location of the chlorine atoms, PCBs with the greatest toxicity are also the most stable and most resistant to degradation. Therefore, from a human health standpoint, the dioxin-like toxicity and persistence of co-planar PCBs make these toxicants the focus of greatest concern among environmental toxicologists.

PCBs were originally manufactured because they are stable, nonflammable compounds with excellent electrical insulating properties. Given the utility of these specific properties, PCBs were used in hundreds of industrial and commercial applications from 1929 until being banned. Nevertheless, municipal and industrial incinerators still release significant amounts of dioxinlike PCBs, and these toxicants also are released into the environment due to leakage from poorly maintained hazardous waste sites as well as leakage from old electrical transformers. Although several studies have reported a decline in the adult human body burden of PCBs and other toxicants over the last decade (for example, Cerna et al, 2003; Uemura et al, 2008), a recent study of North Pacific marine life identified a dramatic increase in total PCB concentration among albatross species compared to concentrations observed in these animals during the preceding decade (Finkelstein et al, 2006). Thus it is likely that regional variations in PCB contamination as well as an individuals dietary choices may lead to the elevated body burdens noted by some investigators (Koninckx, 1999; Heilier et al, 2007). Despite current federal bans and restricted industrial production, these environmental toxicants will continue to cycle in the environment among air, water, soil and, ultimately our food sources, for some time to come; thus, it is important to understand their biological impact.

The U.S. Environmental Protection Agency considers PCBs to be "probable human carcinogens", largely due to the weight of evidence provided by animal studies (EPA Website). Although scientific studies often focus on a specific contaminant, human populations are exposed to complex mixtures of many environmental toxicants with various potential for disrupting biological systems. Among such mixtures of toxicants, coplanar PCBs with dioxinlike activity are more clearly carcinogenic, and epidemiologic data in humans indicates that high-level exposure to these PCBs is associated with an increase in the incidence of hepatocellular carcinoma and malignant melanoma (Brown, 1987; Sinks et al, 1992; Loomis et al, 1997). Within the reproductive tract, coplanar PCBs are particularly suited to act in concert with TCDD to disrupt key elements of communication between the immune and endocrine systems (Aoki, 2001; Bruner-Tran et al, 2008a), potentially promoting reproductive disorders such as endometriosis.

\section{PCBs and the Disease Endometriosis}

Endometriosis, described by pathologists as the presence of endometrial glands and stroma outside the uterus, is a common, benign gynecological disorder affecting millions of women and girls worldwide. The disease is reported to affect $5-10 \%$ of reproductive age women in the U.S.; however, definitive diagnosis requires surgical visualization and thus the actual incidence of the disease is likely higher. Whereas the precise etiology of endometriosis is not known, the invasive implantation and ectopic growth of menstrual tissues outside the uterus following retrograde menstruation remains the most widely accepted causal theory for the disease 
(Sampson, 1927). However, since surgeons frequently note retrograde menstrual tissue within the peritoneum of women without endometriosis (Evers, 1994), the development of clinically significant disease likely involves a more complex etiology than the simple mechanical transfer of endometrial tissue. Given the recognized ability of dioxin-like PCBs to disrupt endometrial physiology in both animals and humans, it is somewhat surprising that these toxicants were only associated with the potential development of endometriosis in a study not originally designed to investigate this disease. More specifically, Rier and colleagues (1993) reported the development of severe endometriosis within a small primate colony in Wisconsin that had been previously exposed to TCDD as part of a dietary study related to fertility. Importantly, the likely co-exposure of these animals to significant levels of dioxin-like PCBs as a result of toxicant contaminated food was later reported in a follow-up study by the same investigators (Rier et al, 2001). Thus, even within a controlled experimental study, it can be difficult to completely exclude additional occult sources of environmental toxicant exposure via food or water.

Following the reports of severe endometriosis in the aforementioned primate colony, a great deal of concern emerged in regard to the role of TCDD and dioxin-like environmental toxicants on the development of endometriosis in human populations. Nevertheless, in spite of more than a decade of animal and human research, no clear understanding of the role of these toxicants on the development of endometriosis has emerged. Most notably, ongoing followup of women living in Seveso, Italy during a 1976 chemical explosion, which released high levels of TCDD into the atmosphere, has not clearly demonstrated an increased incidence of endometriosis although a number of other diseases and conditions have been reported in this cohort (reviewed by Pesatori et al, 2003). In a 20-year follow-up study of the Seveso accident, Eskenazi et al (2002) reported women with serum levels of $\geq 100$ ppt TCDD had a doubled, but statistically insignificant increased risk of endometriosis. It will be important to continue to follow the long-term health of infants and children within this accidentally exposed Italian population in order to determine if developmental exposure to TCDD affects the adult onset of diseases, including endometriosis. The most vulnerable toxicant exposure groups (in utero or neonatal at the time of the accident) are only now reaching their 4th decade of life, when diagnosis of endometriosis typically occurs (Arruda et al, 2003).

As noted in a recent review of PCBs and endometriosis by Anger and Foster (2008), current epidemiological information from several population-based studies fails to uniformly demonstrate a significant relationship between the body burden of a number of dioxin-like PCBs and the presence of endometriosis. Although some studies do suggest an association with certain PCBs and endometriosis (for example, Heilier et al, 2004; 2005; Louis et al, 2005; Jirsová et al, 2005; Porpora et al, 2006; 2009), other studies have failed to find a clear association (for example, Lebel et al, 1998; Pauwels et al, 2001; Fierens et al, 2003; De Felip et al, 2004; Tsukino et al, 2005, Niskar et al, 2009). The reasons for such discrepancy among epidemiology studies abound, including different control populations, different methods for assessment of PCBs, different congeners of PCBs assessed, as well as the use of different approaches for statistical analyses. Additionally, although the concentration of selected PCB congeners is often measured in serum samples, Phillips et al (1989) demonstrated a significant effect of fasting on the measurement of PCBs in serum. More specifically, these investigators found that reducing the serum fat content by fasting resulted in a reduction in measured PCBs and other toxicants. They conclude that "meaningful comparison of analytical results requires standardizing collection procedures or correcting by total serum lipid levels." In this regard, while several studies listed in TABLE 1 did correct for total serum fat (Heilier et al, 2004; Louis et al, 2005; Tsukino et al, 2005; Niskar et al, 2009; Porpora et al, 2009), several studies did not (Pauwels et al, 2001; DeFelip et al, 2004; Porpora et al, 2006) making comparisons between studies difficult. 
In addition to correcting for serum lipids, examining the toxic equivalency quotient (TEQ) is also an important method of assessing the toxicity of mixtures of dioxins and dioxin-like compounds. Eight of the fourteen studies listed in TABLE 1 employed this method; however, no consensus was reached even within this subset. For example, Heilier et al (2005) demonstrated that women with endometriosis (both peritoneal and deep, infiltrating lesions) had an increase in serum TEQ levels compared to controls whereas Tsukino et al (2005) found that the control group had significantly increased TEQ levels compared to endometriosis patients. However, it is significant that the Tsukino et al study included both infertile women and patients with stage I endometriosis within their control population. In contrast, the control group within the Heilier et al study consisted of healthy women with no indications of infertility or endometriosis. Clearly, these differences in selection of control groups likely contributed to the studies differing conclusions.

Equally important, the epidemiological studies listed in TABLE 1 were conducted in seven different countries with varying levels of PCB contamination (TABLE 2). Possible regional differences in levels of contamination were not generally considered in the studies listed in TABLE 1, although it is known that endometriosis is more common in urban rather than rural settings, most likely due to environmental contamination (Koninckx et al, 1999). Furthermore, lactation appears to be a major route of PCB excretion for women (Uemura et al, 2008), yet only four of the TABLE 1 studies included breastfeeding as a characteristic of the study population (Lebel et al, 1998; Heilier et al, 2005;Louis et al, 2005;Porpora et al, 2009) and one study only examined nulliparious women (De Felip et al, 2004). Another possible confounding issue for epidemiological studies is that a person's body burden of PCBs generally increases with age (Uemura et al, 2008;Axelrad et al, 2009), making age-matched comparisons between groups even more critical.

The uncertainty surrounding the conclusions of the multiple epidemiology studies noted above underscores the difficulty in assessing the impact of selected environmental contaminants relative to the presence or absence of endometriosis. Designing such studies difficulties further compounded due to numerous contaminants within any individual or selected population and the clinical uncertainty of accurately diagnosing the presence or absence of endometriosis. For example, Fierens et al, 2003 have suggested that a failure to recognize deep adenomyotic disease as a subset of endometriosis makes it difficult to determine an appropriate disease-free control group for population-based endometriosis studies. Alternatively, deep infiltrating endometriosis may represent a distinctly different disease process and therefore it may not be appropriate to include this phenotype in the same group as women with peritoneal endometriosis (Heilier et al, 2008), although these women appear to have similar environmental risk factors for development of disease (Heilier et al, 2006). Since there is no clear agreement on a definition for endometriosis, or even in choice of a control population, it should not be surprising that, as noted in TABLE 1, small cohort studies have failed to reach a concensus on the relationship between body burden of PCBs and the presence of this disease. However, two recent studies which were able to recruit a larger number of patients and controls were able to demonstrate an association with serum PCBs and the presence of laporascopically confirmed endometriosis (Reddy et al, 2006; Porpora et al, 2009). An important observation from Porpora et al (2009) is that although their results indicate an association between increased selected PCB congeners, the total TEQ (PCBs, dioxin-like PCBs and other organochlorines) was not significantly increased in the patient population. This distinction underscores the possibility that conclusions reached by different authors are likely influenced by the congeners selected for analysis. Additionally, while examining total TEQ seems like a more appropriate approach, it is quite possible that an individual without evidence of disease could have a relatively high TEQ. Specifically, if the majority of PCBs and other toxicants have limited activity, the TEQ may not correlate with disease status since a weak AhR agonist could limit the actions of a more potent compound. For example, using primary rat hepatocytes Chen and Bunce (2004) 
demonstrated that PCB 153, which binds the aryl hydrocarbon receptor (AhR) without inducing CYP1A1 transcription, has no impact on TCDD-mediated CYP1A1 induction when TCDD is present at low levels, but antagonizes the effects of a high dose treatment. Since PCB 153 binds the AhR, this ligand will compete with TCDD for available binding sites, resulting in antagonism when all sites are bound. If more binding sites are present than can be occupied by all ligands, no competition exists; thus, depending on the activity of all ligands, there may be an additive, synergistic or no change in effect.

Another potential source of complexity for any epidemiology study seeking to associate PCBs with endometriosis is whether or not exposure to these toxicants may independently affect fertility. It is known that accidental developmental exposure to dioxin-like PCBs is associated with altered endocrine status in humans (Koopman-Esseboom et al, 1994), potentially influencing the subsequent development of reproductive tract dysfunction and disease. Thus, endometriosis could develop in infertile women as a co-morbidity factor, confounding interpretation of studies which use infertile patients without endometriosis as controls (Pauwels et al, 2001; Tsukino et al, 2005)

As noted above, a lifetime of chronic exposure to various mixtures of PCBs and other dioxinlike toxicants perhaps argues against the value of population-based human toxicology studies that attempt to associate the adult body burden of toxicants at a single point of adult life to the pathophysiology of any disease. Although these confounding issues may be unavoidable within an epidemiological study, even under the best experimental design, measuring the body burden of toxicants in adult women with endometriosis cannot account for the influence of early life toxicant exposures. Given the increased sensitivity of fetuses, infants and children to environmental toxicants (Birnbaum, 1994), early life exposures have become an area of increasing concern, especially for determining whether adult reproductive dysfunction may be due to epigenetic modifications of critical genes during development (Anway and Skinner, 2008). Since controlled developmental human studies are not possible, animal studies have been utilized for early life toxicant exposure models as well as generational studies related to long-term disruption of reproductive capacity. In a murine model of developmental toxicant exposure, we demonstrated that in utero exposure to TCDD followed by adult exposure to the same toxicant results in epigenetic changes in the uterus and reduced fertility (Bruner-Tran et al, 2008b). Interestingly, we noted a progesterone-resistant phenotype in the uterus of TCDDexposed mice that is similar to the endometrial phenotype observed in women with endometriosis (Nayyar et al, 2007). In humans it remains to be determined whether or not developmental versus adult exposure to PCBs and other dioxin-like environmental toxicants affects a woman's overall risk for developing endometriosis. However, toxicant exposure during early periods of human development can trigger epigenetic changes that have been linked to disease processes that only become evident later in life (Dolinoy et al, 2007). Therefore, assessing the impact of PCBs on the pathophysiology of endometriosis will ultimately require a better understanding of the impact of early life exposure, although studies in adults remain critical for the design of better therapeutic strategies. In particular, it is important to study adult tissues in order to understand the key mechanisms of action of these toxicants since the presence of reproductive tract dysfunction only presents at or beyond sexual maturity.

\section{PCB Action and Adult Endometrial Pathophysiology}

Designing therapeutic treatments for disorders associated with prior environmental toxicant exposure demands that we better understand toxicant-mediated disruption of cell behavior within the context of basic tissue physiology. Endometriosis is a disease associated with menstruating species and the incidence of this disease is impacted by a variety of clinical conditions that affect the timing or extent of a woman's menstruation (Cramer, 1987). 
Therefore, our laboratory's endometriosis-related work has focused on toxicant-mediated disruption of biological mechanisms that impact the nature of menstruation. As with all dioxinlike toxicants, the majority of the toxic effects of coplanar PCBs on cell function are mediated by the AhR. The AhR is a ligand activated transcription factor commonly referred to as an orphan nuclear receptor since the endogenous ligand is not known. In the unliganded form, $\mathrm{AhR}$ is present in the cytosol as a multiprotein complex associated with chaperone proteins. Upon ligand binding, the chaperone proteins dissociate and the AhR translocates to the nucleus where it rapidly forms a complex with the aryl hydrocarbon nuclear translocator (ARNT) protein. This heterodimeric AhR/ARNT complex binds to xenobiotic response elements (XREs) and subsequently alters the expression of genes that are impacted directly or indirectly by these response elements. The AhR is abundantly expressed in both the endometrium (Igarashi et al, 1999; Küchenhoff, 1999) as well as in immune cells (Lang et al, 1998), thus exposure to AhR agonists would likely affect the inflammatory-like processes that initiate endometrial menstruation. Indeed, using human endometrial tissue and an organ culture model, we found that even brief exposure of endometrium to TCDD promotes increased secretion of matrix metalloproteinases (MMPs) even in the presence of progesterone, a steroid that normally suppresses the expression of these enzymes at both the mRNA and protein level (Bruner-Tran et al, 1999). In more recent work, we further demonstrated that this toxicant activates an inflammatory-like pattern of cell-cell communication in the human endometrium that disrupts the ability of progesterone to suppress MMP expression in either stromal or epithelial cells (Igarashi et al, 2005; Bruner-Tran et al, 2008a).

Although a potential effect of dioxin-like PCBs on the endometrial MMP system has not been reported, both coplanar and noncoplanar PCBs have been associated with proinflammatory activity and induction of MMP expression associated with tumor metastasis (Eum et al, 2006; Sipka et al, 2008) suggesting that these toxicants would likely affect the endometrium in a similar manner. Importantly, recent studies have revealed that ligand-activated AhR is capable of associating with the estrogen receptor- $\alpha(E R-\alpha)$, potentially affecting the growth related function of this steroid at the level of gene regulation (Ohtake et al, 2003; Matthews et al, 2005). Importantly, it is the ligand-activated AhR that appears to directly interact with the ER (Ohtake et al, 2008), indicating a direct crosstalk between the AhR and the ER- $\alpha$. Although the endogenous physiological ligand for the AhR has not yet been identified, a structurally diverse group of endogenous and exogenous ligands have been determined. Since nuclear receptors undergo conformational changes dependent upon the ligand, activation of the AhR by TCDD or dioxin-like PCBs could result in inappropriate transcriptional regulation of ER targets, such as the progesterone receptor.

Although more work needs to be done, the ability of dioxin-like environmental toxicants to disrupt both estrogen and progesterone action related to regulation of the MMP system provides a potential mechanistic link between environmental toxicant exposure and the invasive pathophysiology of endometriosis. Supporting this assumption, we have shown that toxicantmediated disruption of MMP regulation can increase the invasive behavior of exposed human endometrial tissue in an experimental endometriosis model (Bruner-Tran et al, 1999; 2008a). Additionally, the ability of these toxicants to trigger an acute inflammatory-like endometrial phenotype (Bruner-Tran et al, 2008a) as well as broadly disrupt other elements of the immune system (Rier and Yeaman, 1997; Rier, 2008) further suggests that dioxin-like PCBs could also impact the survival of endometrial fragments within the peritoneal cavity. Normally, fragments of endometrial tissue deposited into the peritoneum via retrograde flow at the time of menstruation should be cleared by the innate immune system; however, immune surveillance is impaired in women with endometriosis (Dmowski and Braun, 2004). Therefore, it is not surprising that alterations in immune cell function have also been noted in women with endometriosis, including a decrease in natural killer (NK) cell cytotoxicity (Kamiński et al, 1995; Oosterlynck et al, 1994) and an enhanced activation state of monocytes and peritoneal 
macrophages (Braun et al, 1996; Rana et al, 1996; Zeller et al, 1987). Taken together, mechanistic studies from our laboratory and others demonstrate that inflammatory-like processes, triggered by dioxin-like environmental toxicants, can disrupt normal endometrial and immune cell physiology in ways that significantly affect the behavior of endometrial tissue within the peritoneal cavity and thus affect the development of endometriosis. In particular, toxicant-mediated disruption of the delicate balance between endometrial somatic cells and resident immune cells may potentially explain the increased invasive behavior noted in endometrial tissue acquired from women with endometriosis in an experimental model of endometriosis (Bruner-Tran et al, 2008a). Future mechanistic studies with human endometrial tissues and cells will need to determine the specific impact of dioxin-like PCBs on the MMP system as well as other key menstruation-related proteins to determine the relative impact of these toxicants compared to published studies that have largely focused on the action of TCDD.

\section{Summary}

The role of human exposure to dioxin-like PCBs in disrupting endometrial physiology related to the development of endometriosis remains speculative in large part due to the inherent difficulties in obtaining accurate early life versus adult exposure histories. In order to better determine the potential role of any environmental toxicant on the development of endometriosis, we and others are utilizing both in vitro and in vivo techniques in order to identify cellular mechanisms of action which may be related to the pathophysiology of specific disease processes (i.e., invasion, inflammation and angiogenesis). Although it is likely that TCDD and dioxin-like PCBs would work in a similar manner to disrupt endometrial physiology related to the pathophysiology of endometriosis, little data exists to support this assumption. Therefore, future studies need to address the degree to which human exposure to mixtures of dioxin-like toxicants at critical stages of early development, puberty and throughout adulthood may collectively contribute to the development of endometriosis. Additionally, as individuals, we have only a limited ability to reduce our lifetime exposure to environmental toxicants; thus, developing a better understanding the basic mechanisms that may allow these toxicants to promote disease will enable us to develop better strategies to reduce the potential toxic impact of these compounds on ourselves and our children.

\section{Acknowledgments}

This work was supported by The National Institute of Environmental Health Sciences grant \#ES014942 and a foundation grant from The International Endometriosis Association.

We greatly appreciate the manuscript preparation assistance provided by Ms. Dana Glore. This work was supported in part by NIEHS ES014942 and The Endometriosis Association.

\section{Abbreviations}

TCDD 2,3,7,8-tetrachlorodibenzo-p-dioxin

PCBs polychlorinated biphenyls

AhR aryl hydrocarbon receptor

MMP matrix metalloproteinase

\section{References}

Anger DL, Foster WG. The link between environmental toxicant exposure and endometriosis. Front Biosci 2008;13:1578-93. [PubMed: 17981650]

Syst Biol Reprod Med. Author manuscript; available in PMC 2010 May 11. 
Anway MD, Skinner MK. Epigenetic programming of the germ line: effects of endocrine disruptors on the development of transgenerational disease. Reprod Biomed Online 2008;16:23-5. [PubMed: 18252044]

Aoki Y. Polychlorinated biphenyls, polychlorinated dibenzo-p-dioxins, and polychlorinated dibenzofurans as endocrine disrupters--what we have learned from Yusho disease. Environ Res 2001;86:2-11. [PubMed: 11386736]

Arruda MS, Petta CA, Abrao MS, Benetti-Pinto CL. Time elapsed from onset of symptoms to diagnosis of endometriosis in a cohort study of Brazilian women. Hum Reprod Apr;2003 18(4):756-9. [PubMed: 12660267]

Axelrad, Daniel A.; Goodman, Stephanie; Woodruf, Tracey J. PCB body burdens in US women of childbearing age 2001-2001: An evaluation of alternate summary metrics of NHANES data. Environ Res May;2009 109(4):368-78. Epub 2009 Feb 28. [PubMed: 19251256]

Ayotte P, Dewailly E, Lambert GH, Perkins SL, Poon R, Feeley M, Larochelle C, Pereg D. Biomarker measurements in a coastal fish-eating population environmentally exposed to organochlorines. Environ Health Perspect Oct;2005 113(10):1318-24. [PubMed: 16203240]

Barbalace, RC. The chemistry of polychlorinated biphenyls. Environmental Chemistry.com. 2003. Website: http://environmentalchemistry.com/yogi/chemistry/pcb.html/

Birnbaum LS. Endocrine effects of prenatal exposure to PCBs, dioxins, and other xenobiotics: implications for policy and future research. Environ Health Perspect 1994;102:676-9. [PubMed: 7895708]

Braun DP, Gebel H, House R, Rana N, Dmowski NP. Spontaneous and induced synthesis of cytokines by peripheral blood monocytes in patients with endometriosis. Fertil Steril 1996;65:1125-9. [PubMed: 8641484]

Brown DP. Mortality of workers exposed to polychlorinated biphenyls--an update. Arch Environ Health 1987;42:333-9. [PubMed: 3125795]

Bruner-Tran KL, Rier SE, Eisenberg E, Osteen KG. The potential role of environmental toxins in the pathophysiology of endometriosis. Gynecol Obstet Invest 1999;48(Suppl 1):45-56. [PubMed: 10559664]

Bruner-Tran KL, Yeaman GR, Crispens MA, Igarashi TM, Osteen KG. Dioxin may promote inflammation-related development of endometriosis. Fertil Steril 2008a;89(5 Suppl):1287-98. [PubMed: 18394613]

Bruner-Tran KL, Crispens MA, Ong DL, Osteen KG. Dietary Supplementation with omega-3 fatty acids reduces the reproductive impact of developmental TCDD exposure in mice. Fert Steril 2008b;90 (Suppl 1):S-50.

Bruner-Tran KL, Ding T, Osteen KG. Dioxin and endometrial progesterone resistance. Seminars in Reprod Med. In Press.

Burton JE, Dorociak IR, Schwedler TE, Rice CD. Circulating lysozyme and hepatic CYP1A activities during a chronic dietary exposure to tributyltin (TBT) and 3,3',4,4',5-pentachlorobiphenyl (PCB-126) mixtures in channel catfish,Ictalurus,punctatus. J Toxicol Environ Health A Apr 26;2002 65(8):589602. [PubMed: 11991632]

Carpenter DO. Polychlorinated biphenyls (PCBs): routes of exposure and effects on human health. Rev Environ Health 2006;21:1-23. [PubMed: 16700427]

Černá M, Šmíd J, Svobodník J, Grabic R, Crhová Š, Kubínová R. Monitoring of selected polyhalogenated hydrocarbons in breast milk: Czech Republic, 1994-2001. Fresen. Environ. Bull 2003;12:203-207.

Chen G, Bunce NJ. Interaction between halogenated aromatic compounds in the Ah receptor signal transduction pathway. Environ Toxicol Oct;2004 19(5):480-9. [PubMed: 15352264]

Crain DA, Janssen SJ, Edwards TM, Heindel J, Ho SM, Hunt P, Iguchi T, Juul A, McLachlan JA, Schwartz J, et al. Female reproductive disorders: the roles of endocrine-disrupting compounds and developmental timing. Fertil Steril 2008;90:911-40. [PubMed: 18929049]

Cramer, DW. Epidemiology of endometriosis in adolescents. Endometriosis. Wilson, EA., editor. Alan Liss, Inc.; NY: 1987. p. 5

De Felip E, Porpora MG, di Domenico A, Ingelido AM, Cardelli M, Cosmi EV, Donnez J. Dioxin-like compounds and endometriosis: a study on Italian and Belgian women of reproductive age. Toxicol Lett 2004;150:203-9. [PubMed: 15093675] 
Dewailly E, Ryan JJ, Laliberté C, Bruneau S, Weber JP, Gingras S, Carrier G. Exposure of remote maritime populations to coplanar PCBs. Environ Health Perspect 1994;102(Suppl 1):205-9. [PubMed: 8187710]

Dhooge W, van Larebeke N, Koppen G, Nelen V, Schoeters G, Vlietinck R, Kaufman JM, Comhaire F, Flemish Environment and Health Study Group. Serum dioxin-like activity is associated with reproductive parameters in young men from the general Flemish population. Environ Health Perspect Nov;2006 114(11):1670-6. [PubMed: 17107851]

Dmowski PW, Braun D,P. Immunology of endometriosis. Best Pract Res Clin Obstet Gynaecol 2004;18:245-63. [PubMed: 15157641]

Dolinoy DC, Weidman JR, Jirtle RL. Epigenetic gene regulation: linking early developmental environment to adult disease. Reprod Toxicol 2007;23:297-307. [PubMed: 17046196]

Environmental Working Group. Body Burden-The Pollution in Newborns: A benchmark investigation of industrial chemicals, pollutants and pesticides in umbilical cord blood. 2005. Website: http://www.ewg.org/reports/bodyburden2/execsumm.php

Eskenazi B, Mocarelli P, Warner M, Samuels S, Vercellini P, Olive D, Needham LL, Patterson DG Jr, Brambilla P, Gavoni N, Casalini S, Panazza S, Turner W, Gerthoux PM. Serum dioxin concentrations and endometriosis: a cohort study in Seveso, Italy. Environ Health Perspect Jul;2002 110(7):629_ 34. [PubMed: 12117638]

Eum SY, Lee YW, Hennig B, Toborek M. Interplay between epidermal growth factor receptor and Janus kinase 3 regulates polychlorinated biphenyl-induced matrix metalloproteinase- 3 expression and transendothelial migration of tumor cells. Mol Cancer Res Jun;2006 4(6):361-70. [PubMed: 16778083]

Evers JL. Endometriosis does not exist; all women have endometriosis. Hum Reprod 1994;9:2206-9. [PubMed: 7714129]

Fierens S, Mairesse H, Heilier JF, De Burbure C, Focant JF, Eppe G, De Pauw E, Bernard A. Dioxin/ polychlorinated biphenyl body burden, diabetes and endometriosis: findings in a population-based study in Belgium. Biomarkers 2003;8:529-34. [PubMed: 15195683]

Finkelstein M, Keitt BS, Croll DA, Tershy B, Jarman WM, Rodriguez-Pastor S, Anderson DJ, Sievert PR, Smith DR. Albatross species demonstrate regional differences in North Pacific marine contamination. Ecol Appl Apr;2006 16(2):678-86. [PubMed: 16711054]

Harrad S, Wang Y, Sandaradura S, Leeds A. Human dietary intake and excretion of dioxin-like compounds. J Environ Monit 2003;5:224-8. [PubMed: 12729259]

Heilier JF, Ha AT, Lison D, Donnez J, Tonglet R, Nackers F. Increased serum polychlorobiphenyl levels in Belgian women with adenomyotic nodules of the rectovaginal septum. Fertil Steril 2004;81:4568. [PubMed: 14967391]

Heilier JF, Nackers F, Verougstraete V, Tonglet R, Lison D, Donnez J. Increased dioxin-like compounds in the serum of women with peritoneal endometriosis and deep endometriotic (adenomyotic) nodules. Fertil Steril 2005;84:305-12. [PubMed: 16084869]

Heilier JF, Donnez J, Nackers F, Rousseau R, Verougstraete V, Rosenkranz K, Donnez O, Grandjean F, Lison D, Tonglet R. Environmental and host-associated risk factors in endometriosis and deep endometriotic nodules: a matched case-control study. Environ Res Jan;2007 103(1):121-9. [PubMed: 16781705]

Heilier JF, Donnez J, Defrere S, Van Kerckhove V, Donnez O, Lison D. Serum dioxin-like compounds and aromatase (CYP19) expression in endometriotic tissues. Toxicol Lett Dec 15;2006 167(3):23844. [PubMed: 17112691] Heilier JF, Donnez J, Lison D. Organochlorines and endometriosis: a minireview. Chemosphere 2008;71:203-10. [PubMed: 18006040]

Heindel JJ. Role of exposure to environmental chemicals in the developmental basis of reproductive disease and dysfunction. Semin Reprod Med 2006;24:168-77. [PubMed: 16804815]

Igarashi T, Osuga U, Tsutsumi O, Momoeda M, Ando K, Matsumi H, Takai Y, Okagaki R, Hiroi H, Fujiwara $\mathrm{O}$, et al. Expression of Ah receptor and dioxin-related genes in human uterine endometrium in women with or without endometriosis. Endocr J 1999;46:765-72. [PubMed: 10724351]

Igarashi TM, Bruner-Tran KL, Yeaman GR, Lessey BA, Edwards DP, Eisenberg E, Osteen KG. Reduced expression of progesterone receptor-B in the endometrium of women with endometriosis and in 
cocultures of endometrial cells exposed to 2,3,7,8-tetrachlorodibenzo-p-dioxin. Fertil Steril 2005;84:67-74. [PubMed: 16009159]

Jacobson-Dickman E, Lee MM. The influence of endocrine disruptors on pubertal timing. Curr Opin Endocrinol Diabetes Obes 2009;16:25-30. [PubMed: 19115521]

Jirsová S, Masata JV, Drbohlavá P, Pavelkova J, Jech L, Omelka M, Zvárová J. Differences in the polychlorinated biphenyl levels in follicular fluid in individual types of sterility. Ceska Gynekol 2005;70:262-8. [PubMed: 16128124]

Kamiński K, Kotarski J, Gogacz M. Characterization of cellular components in the peritoneal fluid and in the endometrial tissue of women with endometriosis. Arch Immunol Ther Exp (Warsz) 1995;43:247-52. [PubMed: 8744643]

Koopman-Esseboom C, Morse DC, Weisglas-Kuperus N, Lutkeschipholt IJ, Van der Paauw CG, Tuinstra LG, Brouwer A, Sauer PJ. Effects of dioxins and polychlorinated biphenyls on thyroid hormone status of pregnant women and their infants. Pediatr Res 1994;36:468-73. [PubMed: 7816522]

Koninckx PR. The physiopathology of endometriosis: pollution and dioxin. Gynecol Obstet Invest 1999;47(Suppl 1):47-9. [PubMed: 10087428]

Koppen G, Den Hond E, Nelen V, Van De Mieroop E, Bruckers L, Bilau M, Keune H, Van Larebeke N, Covaci A, Van De Weghe H, Schroijen C, Desager K, Stalpaert M, Baeyens W, Schoeters G. Organochlorine and heavy metals in newborns: Results from the Flemish Environment and Health Survey (FLEHS 2002-2006). Environ Int. 2009 Doi:10.1016/j.envint.2009.05.002.

Küchenhoff A, Seliger G, Klonisch T, Tscheudschilsuren G, Kaltwasser P, Seliger E, Buchmann J, Fischer B. Arylhydrocarbon receptor expression in the human endometrium. Fertil Steril 1999;71:354-60. [PubMed: 9988411]

Kunisue T, Watanabe M, Iwata H, Subramanian A, Monirith I, Minh TB, Baburajendran R, Tana TS, Viet PH, Prudente M, Tanabe S. Dioxins and related compounds in human breast milk collected around open dumping sites in Asian developing countries: bovine milk as a potential source. Arch Environ Contam Toxicol Oct;2004 47(3):414-26. [PubMed: 15386136]

Lebel G, Dodin S, Ayotte P, Marcoux S, Ferron LA, Dewailly E. Organochlorine exposure and the risk of endometriosis. Fertil Steril 1998;69:221-8. [PubMed: 9496332]

Lang DS, Becker S, Devlin RB, Koren HS. Cell-specific differences in the susceptibility of potential cellular targets of human origin derived from blood and lung following treatment with 2,3,7,8tetrachlorodibenzo-p-dioxin (TCDD). Cell Biol Toxicol 1998;14:23-38. [PubMed: 9538942]

Loeffler IK, Peterson RE. Interactive effects of TCDD and p,p'-DDE on male reproductive tract development in in utero and lactationally exposed rats. Toxicol Appl Pharmacol Jan 1;1999 154(1): 28-39. [PubMed: 9882589]

Loomis D, Browning SR, Schenck AP, Gregory E, Savitz DA. Cancer mortality among electric utility workers exposed to polychlorinated biphenyls. Occup Environ Med 1997;54:720-8. [PubMed: 9404319]

Louis GM, Weiner JM, Whitcomb BW, Sperrazza R, Schisterman EF, Lobdell DT, Crickard K, Greizerstein H, Kostyniak PJ. Environmental PCB exposure and risk of endometriosis. Hum Reprod 2005;20:279-85. [PubMed: 15513976]

Matthews J, Wihlén B, Thomsen J, Gustafsson JA. Aryl hydrocarbon receptor-mediated transcription: ligand-dependent recruitment of estrogen receptor alpha to 2,3,7,8-tetrachlorodibenzo-p-dioxinresponsive promoters. Mol Cell Biol Jul;2005 25(13):5317-28. [PubMed: 15964790]

Nayyar T, Bruner-Tran KL, Piestrzeniewicz-Ulanska D, Osteen KG. Developmental exposure of mice to TCDD elicits a similar uterine phenotype in adult animals as observed in women with endometriosis. Reprod Toxicol 2007;23:326-36. [PubMed: 17056225]

Niskar AS, Needham LL, Rubin C, Turner WE, Martin CA, Patterson DG Jr, Hasty L, Wong LY, Marcus M. Serum dioxins, polychlorinated biphenyls, and endometriosis: a case-control study in Atlanta. Chemosphere 2009;74:944-9. [PubMed: 19027927]

Ohtake F, Takeyama K, Matsumoto T, Kitagawa H, Yamamoto Y, Nohara K, Tohyama C, Krust A, Mimura J, Chambon P, Yanagisawa J, Fujii-Kuriyama Y, Kato S. Modulation of oestrogen receptor signalling by association with the activated dioxin receptor. Nature May 29;2003 423(6939):54550. [PubMed: 12774124] 
Ohtake F, Baba A, Fujii-Kuriyama Y, Kato S. Intrinsic AhR function underlies cross-talk of dioxins with sex hormone signalings. Biochem Biophys Res Commun Jun 13;2008 370(4):541-6. [PubMed: 18358233]

Oosterlynck DJ, Meuleman C, Waer M, Koninckx PR. $\mathrm{CO}_{2}$-laser excision of endometriosis does not improve the decreased natural killer activity. Acta Obstet Gynecol Scand 1994;73:333-7. [PubMed: 8160542]

Patterson DG Jr, Turner WE, Caudill SP, Needham LL. Total TEQ reference range (PCDDs, PCDFs, cPCBs, mono-PCBs) for the US population 2001-2002. Chemosphere Aug;2008 73(1 Suppl):S26177. [PubMed: 18511103]

Pauwels A, Schepens PJ, D'Hooghe T, Delbeke L, Dhont M, Brouwer A, Weyler J. The risk of endometriosis and exposure to dioxins and polychlorinated biphenyls: a case-control study of infertile women. Hum Reprod 2001;16:2050-5. [PubMed: 11574490]

Pesatori AC, Consonni D, Bachetti S, Zocchetti C, Bonzini M, Baccarelli A, Bertazzi PA. Short- and long-term morbidity and mortality in the population exposed to dioxin after the "Seveso accident". Ind Health Jul;2003 41(3):127-38. [PubMed: 12916742]

Phillips DL, Pirkle JL, Burse VW, Bernert JT Jr, Henderson LO, Needham LL. Chlorinated hydrocarbon levels in human serum: effects of fasting and feeding. Arch Environ Contam Toxicol Jul-Aug;1989 18(4):495-500. [PubMed: 2505694]

Pompa G, Caloni F, Fracchiolla ML. Dioxin and PCB contamination of fish and shellfish: assessment of human exposure. Review of the international situation. Vet Res Commun 2003;27(Suppl 1):159-67. [PubMed: 14535384]

Porpora MG, Ingelido AM, di Domenico A, Ferro A, Crobu M, Pallante D, Cardelli M, Cosmi EV, De Felip E. Increased levels of polychlorobiphenyls in Italian women with endometriosis. Chemosphere May;2006 63(8):1361-7. [PubMed: 16289286]

Porpora MG, Medda E, Abballe A, Bolli S, De Angelis I, di Domenico A, Ferro A, Ingelido AM, Maggi A, Panici PB, De Felip E. Endometriosis and Organochlorinated Environmental Pollutants: A CaseControl Study on Italian Women of Reproductive Age. Environmental Health Perspectives 2009;117:1070-1075. [PubMed: 19654915]

Rana N, Braun DP, House R, Gebel H, Rotman C, Dmowski WP. Basal and stimulated secretion of cytokines by peritoneal macrophages in women with endometriosis. Fertil Steril 1996;65:925-30. [PubMed: 8612850]

Reddy BS, Rozati R, Reddy S, Kodampur S, Reddy P, Reddy R. High plasma concentrations of polychlorinated biphenyls and phthalate esters in women with endometriosis: a prospective case control study. Fertil Steril Mar;2006 85(3):775-9. [PubMed: 16500362]

Rier S, Foster WG. Environmental dioxins and endometriosis. Semin Reprod Med 2003;21:145-54. [PubMed: 12917784]

Rier SE, Martin DC, Bowman RE, Dmowski WP, Becker JL. Endometriosis in rhesus monkeys (Macaca mulatta) following chronic exposure to 2,3,7,8-tetrachlorodibenzo-p-dioxin. Fundam Appl Toxicol 1993;21:433-41. [PubMed: 8253297]

Rier SE, Turner WE, Martin DC, Morris R, Lucier GW, Clark GC. Serum levels of TCDD and dioxinlike chemicals in Rhesus monkeys chronically exposed to dioxin: correlation of increased serum PCB levels with endometriosis. Toxicol Sci 2001;59:147-59. [PubMed: 11134554]

Rier SE. Environmental immune disruption: a comorbidity factor for reproduction? Fertil Steril 2008;89 (2 Suppl):e103-8. [PubMed: 18308048]

Rier SE, Yeaman GR. Immune aspects of endometriosis: relevance of the uterine mucosal immune system. Semin Reprod Endocrinol 1997;15:209-20. [PubMed: 9383829]

Rocca CL, Alivernini S, Badiali M, Cornoldi A, Iacovella N, Silvestroni L, et al. TEQ(S) and body burden for PCDDs, PCDFs, and dioxin-like PCBs in human adipose tissue. Chemosphere Aug;2008 73(1): 92-6. [PubMed: 18585755]

Rusiecki JA, Matthews A, Sturgeon S, Sinha R, Pellizzari E, Zheng T, Baris D. A correlation study of organochlorine levels in serum, breast adipose tissue, and gluteal adipose tissue among breast cancer cases in India. Cancer Epidemiol Biomarkers Prev May;2005 14(5):1113-24. [PubMed: 15894661]

Sampson JA. Peritoneal endometriosis due to menstrual dissemination of endometrial tissues into the peritoneal cavity. Am J Obstet Gynecol 1927;14:422-469. 
Schecter A, Wallace D, Pavuk M, Piskac A, Päpke O. Dioxins in commercial United States baby food. J Toxicol Environ Health 2002;65:1937-43.

Scott LL, Unice KM, Scott P, Nguyen LM, Haws LC, Harris M, Paustenbach D. Addendum to: Evaluation of PCDD/F and dioxin-like PCB serum concentration data from the 2001-2002 National Health and Nutrition Examination Survey of the United States population. J Expo Sci Environ Epidemiol Sep; 2008 18(5):524-32. [PubMed: 18368012]

Sipka S, Eum SY, Son KW, Xu S, Gavalas VG, Hennig B, Toborek M. Oral administration of PCBs induces proinflammatory and prometastatic responses. Environ Toxicol Pharmacol Mar;2008 25(2): 251-259. [PubMed: 18438459]

Sinks T, Steele G, Smith AB, Watkins K, Shults RA. Mortality among workers exposed to polychlorinated biphenyls. Am J Epidemiol 1992;136:389-98. [PubMed: 1415158]

Tsuchiya M, Tsukino H, Iwasaki M, Sasaki H, Tanaka T, Katoh T, Patterson DG Jr, Turner W, Needham $\mathrm{L}$, Tsugane S. Interaction between cytochrome P450 gene polymorphisms and serum organochlorine TEQ levels in the risk of endometriosis. Mol Hum Reprod Jun;2007 13(6):399-404. [PubMed: 17449539]

Tsukino H, Hanaoka T, Sasaki H, Motoyama H, Hiroshima M, Tanaka T, Kabuto M, Niskar AS, Rubin C, Patterson DG Jr. et al. Associations between serum levels of selected organochlorine compounds and endometriosis in infertile Japanese women. Environ Res 2005;99:118-25. [PubMed: 15927178]

Tsukino H, Hanaoka T, Sasaki H, Motoyama H, Hiroshima M, Tanaka T, Kabuto M, Turner W, Patterson DG Jr, Needham L, Tsugane S. Fish intake and serum levels of organochlorines among Japanese women. Sci Total Environ Apr 15;2006 359(1-3):90-100. [PubMed: 16546516]

Uemura H, Arisawa K, Hiyoshi M, Satoh H, Sumiyoshi Y, Morinaga K, Kodama K, Suzuki T, Nagai M, Suzuki T. PCDDs/PCDFs and dioxin-like PCBs: recent body burden levels and their determinants among general inhabitants in Japan. Chemosphere Aug;2008 73(1):30-7. Epub 2008 Jul 15. [PubMed: 18632132]

Apr. 2009 U.S. Environmental Protection Agency Website: http://www.epa.gov/epawaste/hazard/tsd/pcbs/index.htm/

Woodruff TJ, Carlson A, Schwartz JM, Giudice LC. Proceedings of the Summit on Environmental Challenges to Reproductive Health and Fertility: executive summary. Fertil Steril 2008;89(2 Suppl):e1-e20. [PubMed: 18308046]

Zeller JM, Henig I, Radwanska E, Dmowski WP. Enhancement of human monocyte and peritoneal macrophage chemiluminescence activities in women with endometriosis. Am J Reprod Immunol Microbiol 1987;13:78-82. [PubMed: 3605484]

Zhao B, Yang J, Liu Z, Xu Z, Qiu Y, Sheng G. Joint anti-estrogenic effects of PCP and TCDD in primary cultures of juvenile goldfish hepatocytes using vitellogenin as a biomarker. Chemosphere Oct;2006 65(3):359-64. [PubMed: 16571359] 


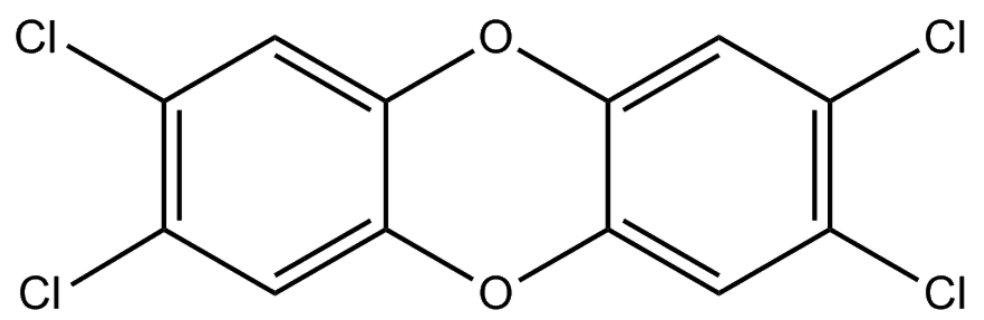

2,3,7,8-tetrachlorodibenzo-p-dioxin

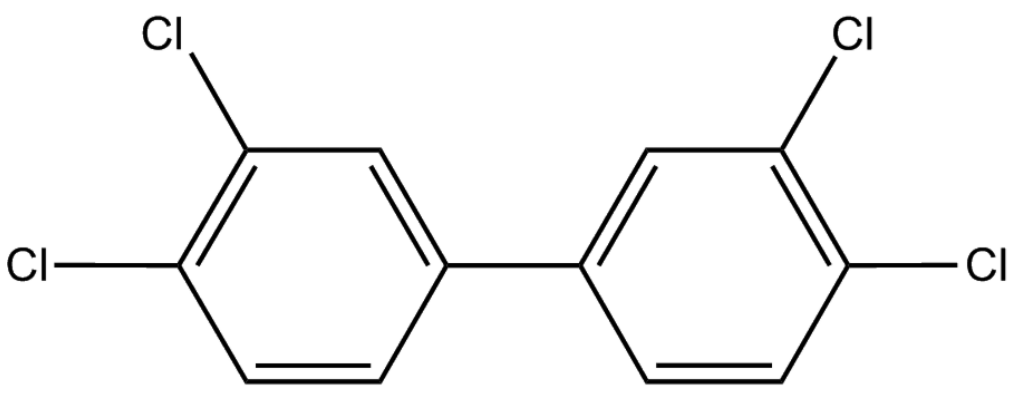

3,3',4,4' tetrachlorobiphenyl coplanar

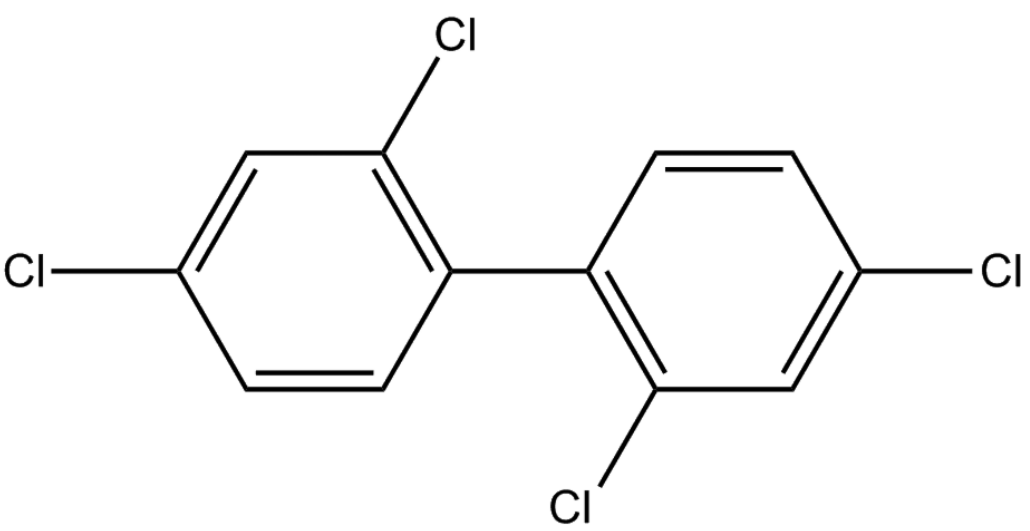

$3,3^{\prime}, 4,4^{\prime}$ tetrachlorobiphenyl non coplanar

Figure 1.

Chemical structure of 2,3,7,8-tetrachlorodibenzo-p-dioxin (TCDD) as well as the chemical structures for 3,3',4,4' tetrachlorobiphenyl and 2,2',4,4' tetrachlorobiphenyl, examples coplanar and noncoplanar PCBs. 


\begin{tabular}{|c|c|c|c|c|c|}
\hline 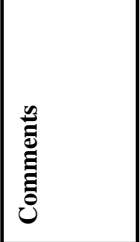 & 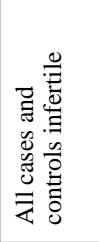 & 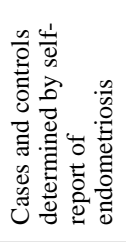 & 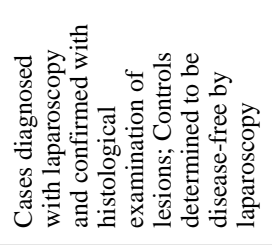 & 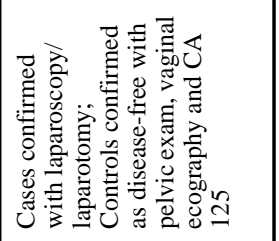 & 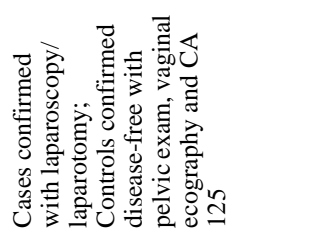 \\
\hline 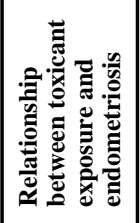 & 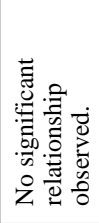 & 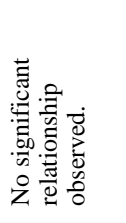 & 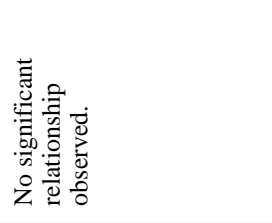 & 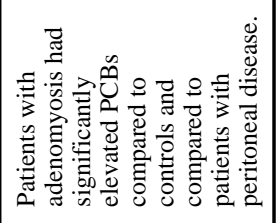 & 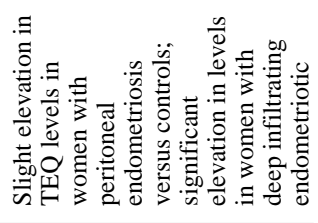 \\
\hline
\end{tabular}

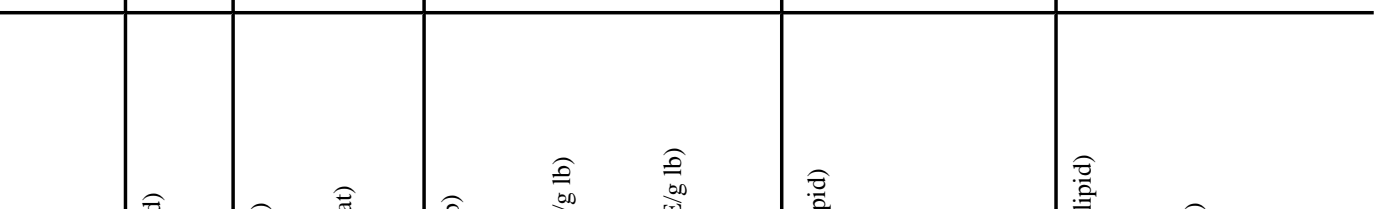

急

छี

3

흥

:

4

क्षี

כ

궁

宓

$\stackrel{2}{ \pm}$

苜

\begin{tabular}{|c|c|c|c|c|c|}
\hline 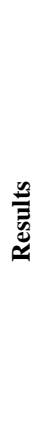 & 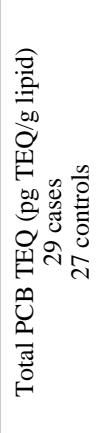 & 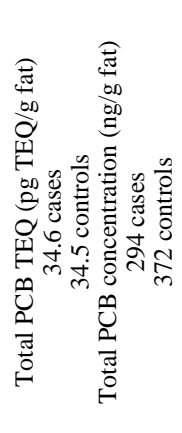 & 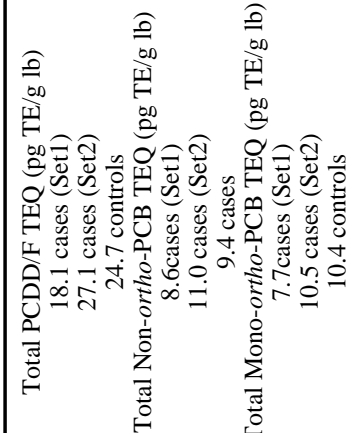 & 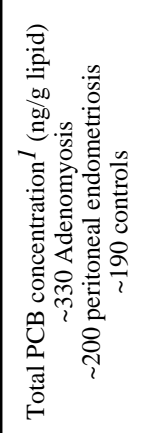 & 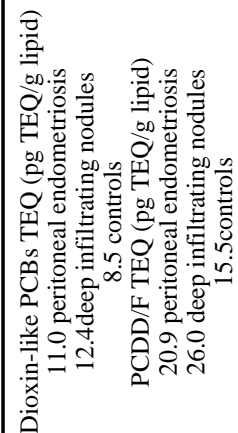 \\
\hline 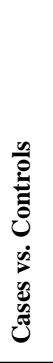 & 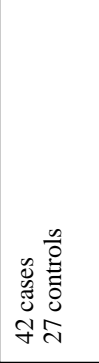 & 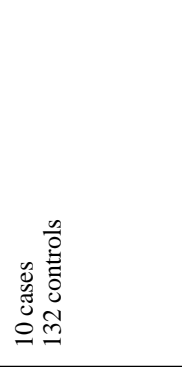 & 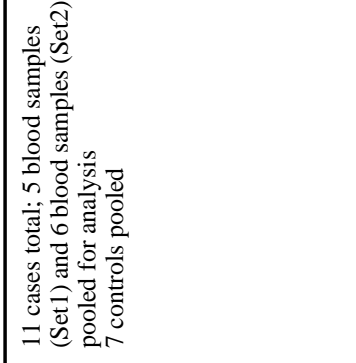 & 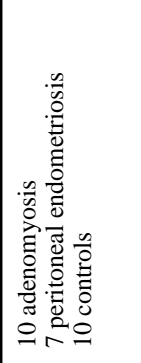 & 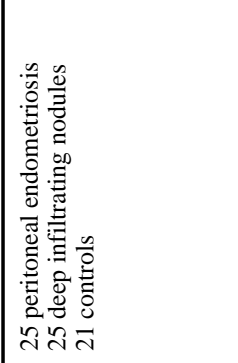 \\
\hline 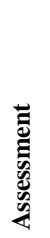 & 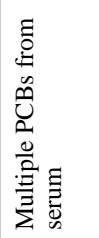 & 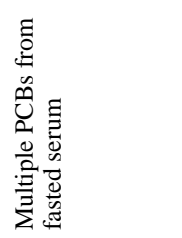 & 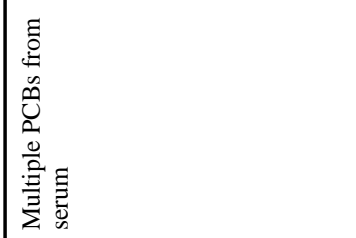 & 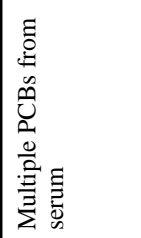 & 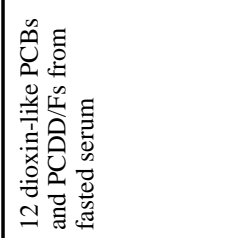 \\
\hline 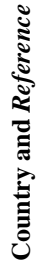 & 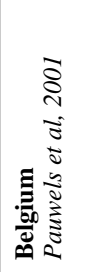 & 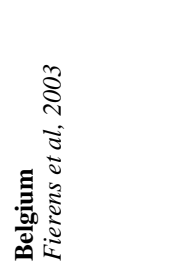 & 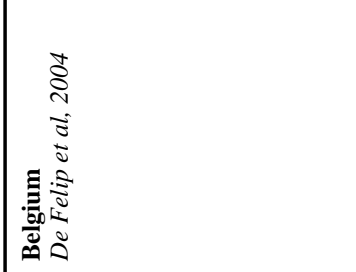 & 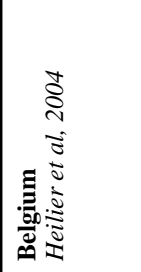 & 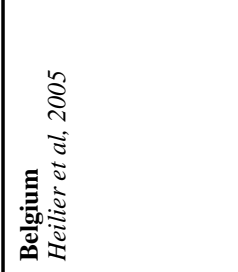 \\
\hline
\end{tabular}




\begin{tabular}{|c|c|c|c|c|c|c|c|}
\hline ठै & & 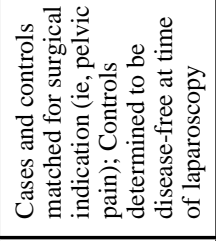 & 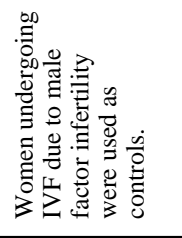 & 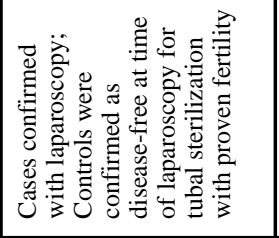 & 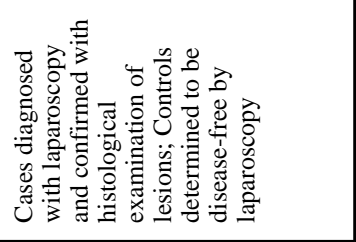 & 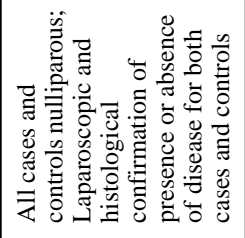 & 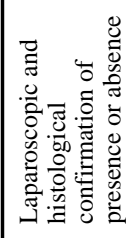 \\
\hline 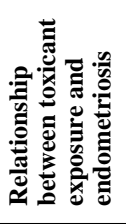 & 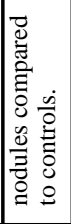 & 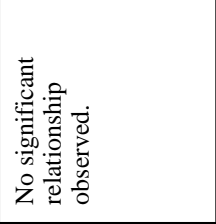 & 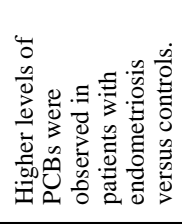 & 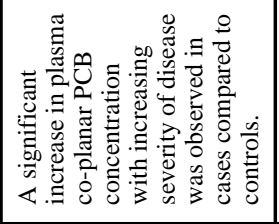 & 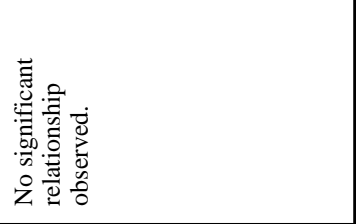 & 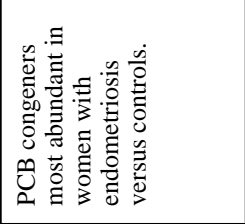 & 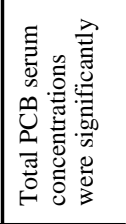 \\
\hline 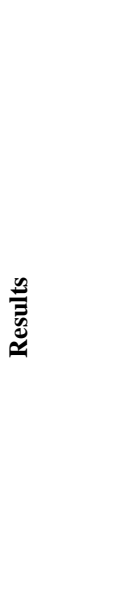 & & 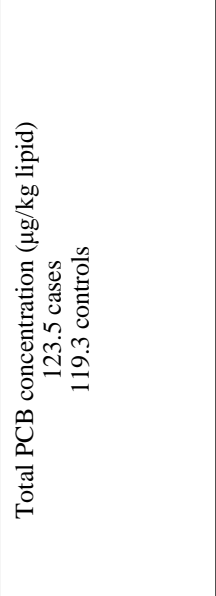 & 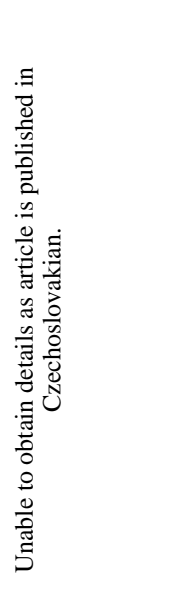 & 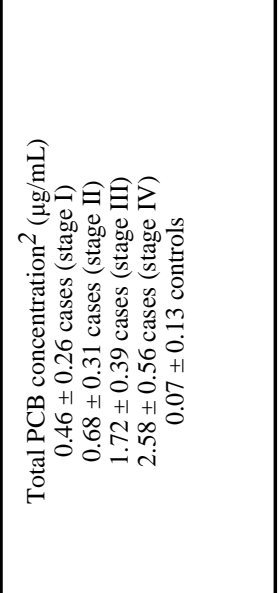 & 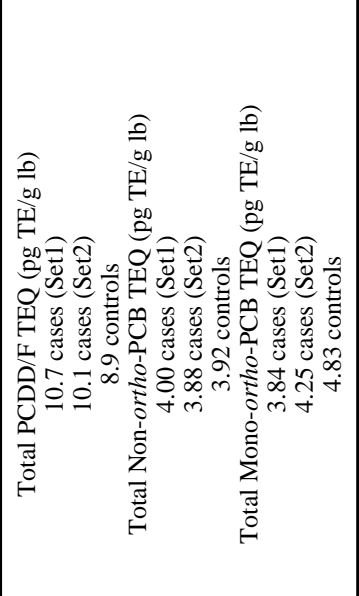 & 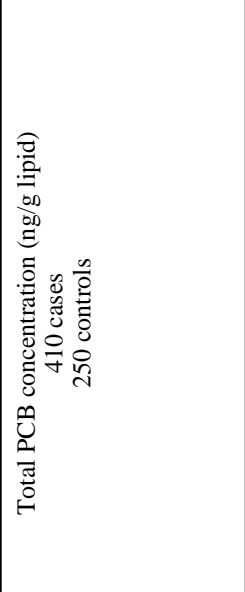 & 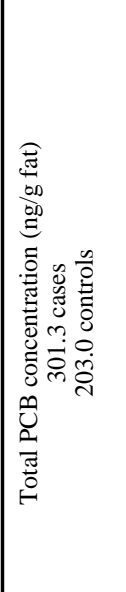 \\
\hline 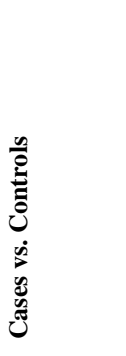 & & 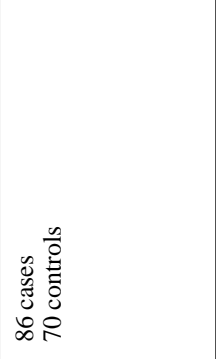 & 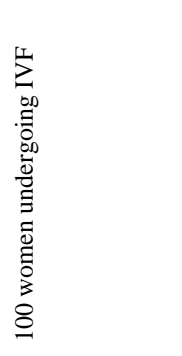 & 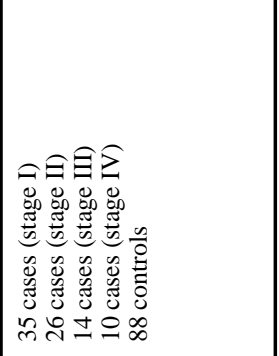 & 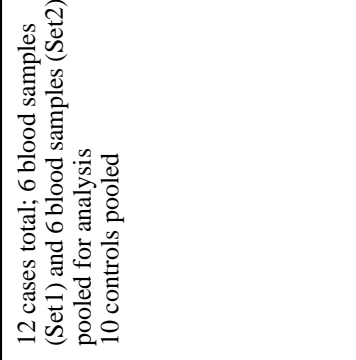 & 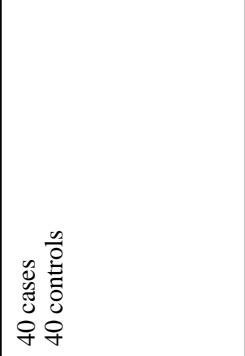 & 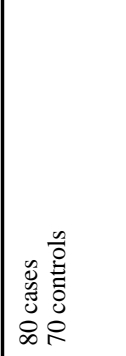 \\
\hline 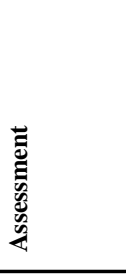 & & 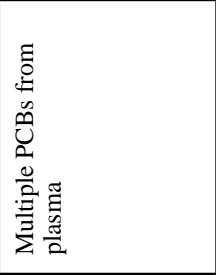 & 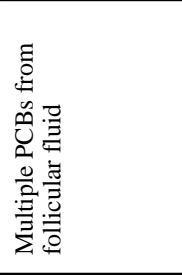 & 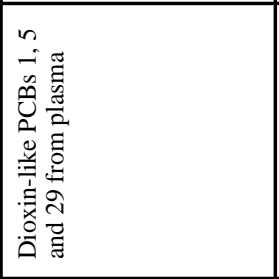 & 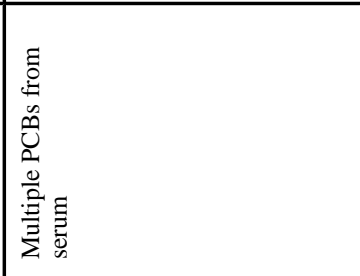 & 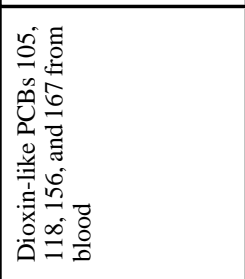 & 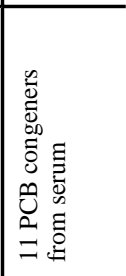 \\
\hline 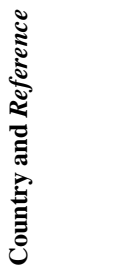 & & 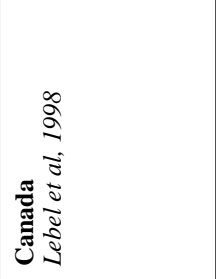 & 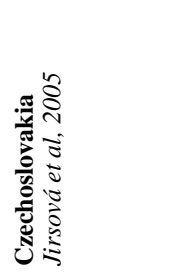 & 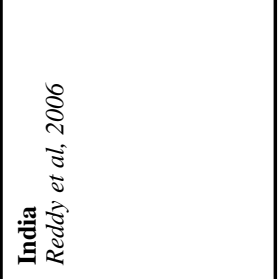 & 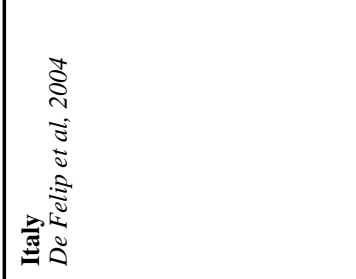 & 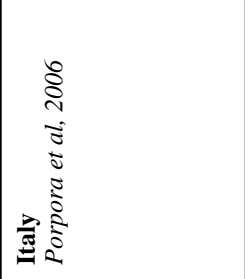 & 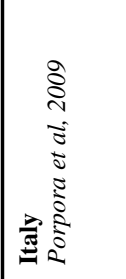 \\
\hline
\end{tabular}




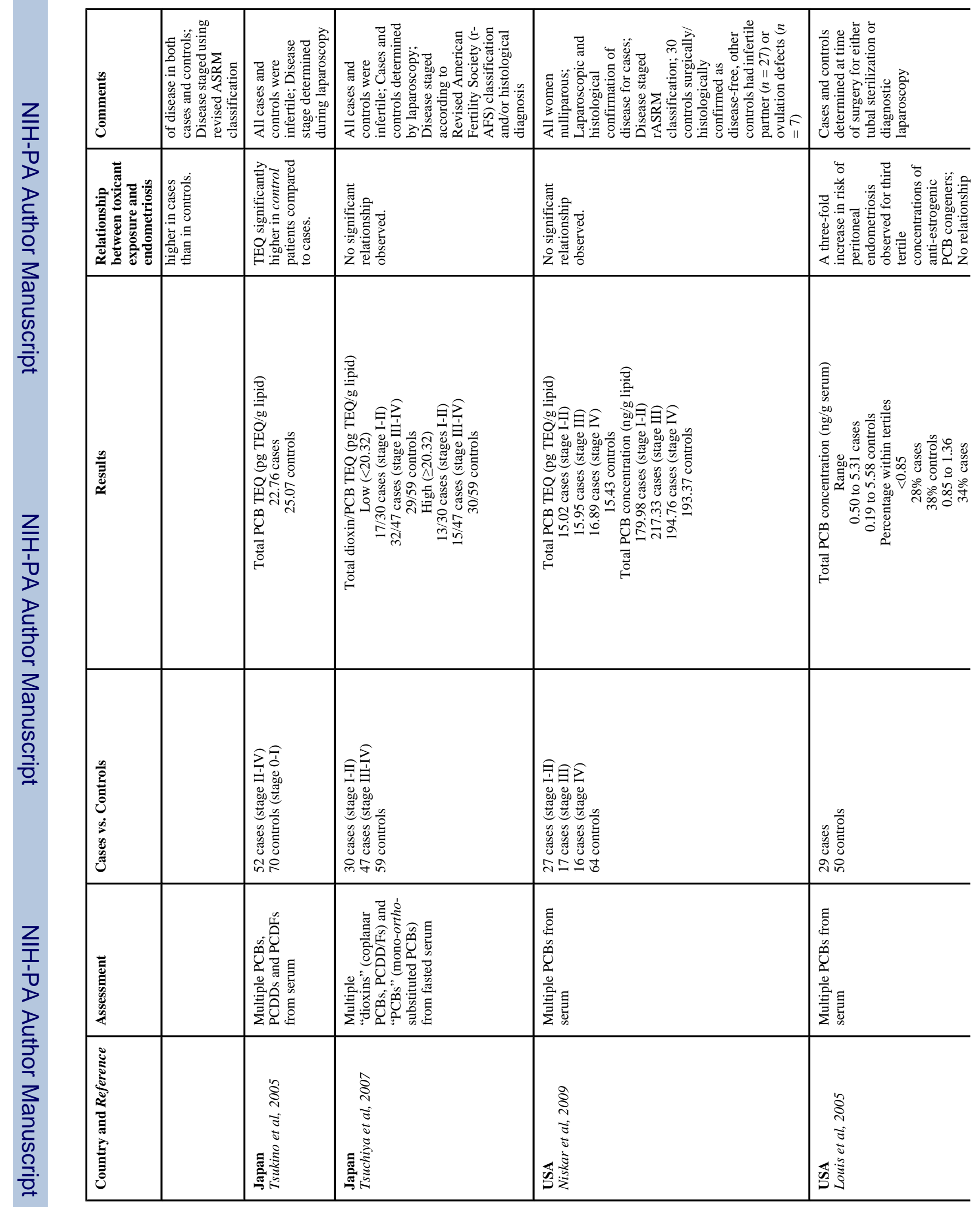




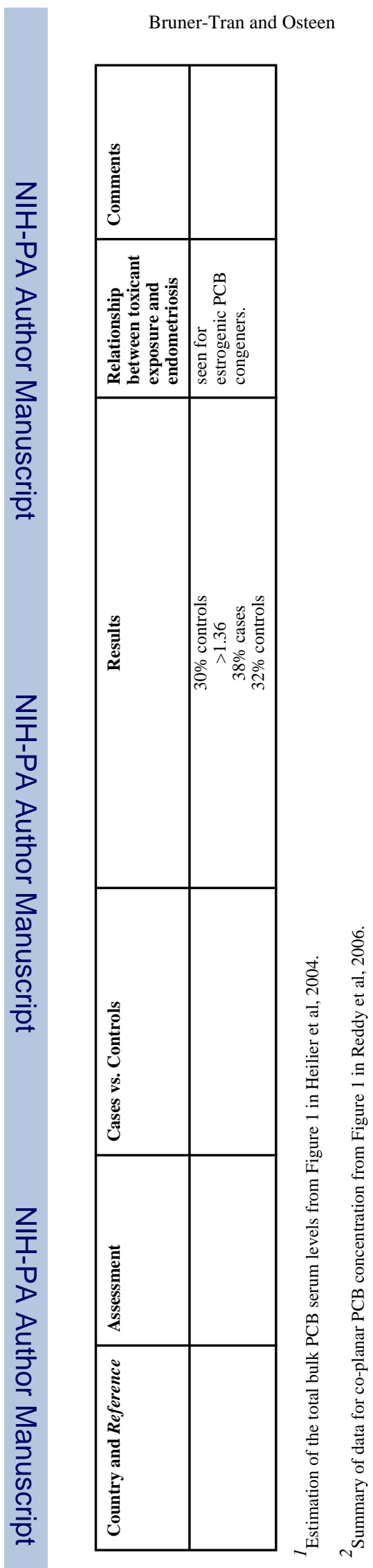

Page 18 


\section{Table 2}

Differences in Toxic Equivalency Quotient (TEQ) in selected countries. Although analysis was conducted on different sample types, studies have indicated that analysis of PCBs within various tissues gives similar results following adjustment for lipid content (for example, Rusiecki et al, 2005).

\begin{tabular}{|l|l|l|l|l|}
\hline Country & Reference & Mean or Median & Sample & Comments \\
\hline Canada & Ayotte, 2005 & 93 ngTEQ/kg lipid & Plasma & Dioxin-like Compounds \\
\hline & & & & \\
\hline Belgium & Koppen, 2009 & $23 \mathrm{pgCALUX-TEQ/g} \mathrm{lipid}$ & Cord Blood & Dioxin-like Compounds \\
\hline & Dhooge, 2006 & $11.9 \mathrm{pgCALUX-TEQ/g} \mathrm{lipid}$ & Serum & Dioxin-like Compounds \\
\hline Italy & Rocca, 2008 & $8.85 \mathrm{ngTEQ/kg} \mathrm{body} \mathrm{weight}$ & Adipose tissue & Mixture \\
\hline & & & & \\
\hline India & Kunisue, 2005 & $12 \mathrm{pgTEQ/g} \mathrm{lipid}$ & Breast Milk & Mixture \\
\hline Czech & Cerna et al, 2003 & $32.1 \mathrm{pgTEQ/g} \mathrm{lipid}$ & Breast Milk & Mixture \\
\hline Japan & Uemura, 2008 & $7.6 \mathrm{pgTEQ/g} \mathrm{lipid}$ & Whole blood & Dioxin-like PCBs \\
\hline & Tsukino, 2006 & $25.1 \mathrm{pgTEQ/g} \mathrm{lipid}$ & serum & Mixture \\
\hline & & & & Mixture \\
\hline USA & Scott, 2008 & $13.3 \mathrm{ngTEQ/g} \mathrm{lipid}$ & Serum & Mixture \\
\hline & Patterson, 2008 & $41.1 \mathrm{pgTEQ/g} \mathrm{lipid}$ & Serum & \\
\hline
\end{tabular}

